\title{
PEMBAYARAN HUTANG MELALUI HASIL PENJUALAN UBI PRESPEKTIF FIQH MUAMALAH \\ (Studi Kasus di Jorong Sungai Jambu Nagari Sungai Jambu Kecamatan Pariangan Kabupaten Tanah Datar)
}

\author{
Zulkifli W' $^{1}$, Fitri Yeni Dalil ${ }^{2}$ \\ ${ }^{1}$ Institut Agama Islam Negeri Batusangkar \\ e-mail:wsjzulkifli@gmail.com \\ ${ }^{2}$ Institut Agama Islam Negeri Batusangkar \\ e-mail: fitriyenidalil@iainbatusangkar.ac.id
}

\begin{abstract}
This study examines the implementation of the debt agreement of sweet potato farmers with toke yam, the mechanism for payment of money owed by sweet potato farmers to toke yam and a review of muamalah fiqh on the implementation of conditional debt and debt payment mechanisms according to muamalah fiqh. The type of research used is field research (field research). The findings of this research are, first, the implementation of debt between sweet potato farmers and sweet potato farmers, namely Toke gives debt to farmers on the condition that farmers must sell their sweet potato harvests to Toke and Toke buys the sweet potatoes at a price set by Toke bimself. Second, the mechanism for payment of debt between farmers and toke ubi is through the sale of sweet potatoes which are cut directly by toke ubi as a form of debt payment. Third, the implementation of debts between farmers and tokens is contrary to the tabarru contract and in buying and selling there is an element of coercion or lack of willingness and toke to take profits that are not their rights.
\end{abstract}

Keywords: Fikih Muamalah, Hutang, Jual Beli.

\section{PENDAHULUAN}

Kewajiban bagi setiap muslim untuk saling tolong menolong dan telah menjadi kehendak Allah SWT bahwa manusia harus hidup bermasyarakat dan saling tolong menolong. Manusia tidak bisa bertahan hidup tanpa berinteraksi dan berkomunikasi dengan manusia lain (Putri, 2018: 141). Manusia adalah makhluk sosial, yaitu makhluk yang berkodrat hidup dalam masyarakat. Sebagai makhluk sosial, dalam hidupnya manusia memerlukan adanya manusiamanusia lain yang bersama-sama hidup dalam masyarakat. Dalam hidup bermasyarakat, manusia selalu berhubungan satu sama lain, disadari atau tidak, untuk mencukupkan kebutuhan-kebutuhan hidupnya (Basyir, 2000: 11).

Dalam aspek tolong menolong yakni aspek perekonomian keluarga, sesama umat muslim harus saling memberi dan saling gotong royong terhadap masyarakat yang membutuhkan, bahwasanya Islam telah memperbolehkan tolong menolong apalagi dalam aspek perekonomian. Salah satu contohnya adalah tolong menolong dalam pelaksanaan upacara adat di suatu daerah (Putri, 2020: 73).

Dalam rangka menciptakan kesejahteraan dan kemakmuran bersama hal ini manusia 
dituntut untuk melakukan uasaha dan bekerja. Dalam Islam pun sudah diatur, bahwasanya manusia dituntut untuk bekerja dan menyebar di muka bumi dan memanfaatkan rezki yang telah diatur oleh Alla SWT, yang tidak harus berdiam diri menunggu rezki dari Allah datang, dengan bekerja manusia akan memperoleh penghasilan yang dapat melangsungkan kehidupannya dan dapat memenuhi kebutuhan keluarganya, tanpa harus menunggu bantuan dari orang lain atau masyarakat lain. Kebutuhan ekonomi yang telah menjadikan para masyarakat mengambil utang demi kelangsungan hidup merupakan hal yang tak asing bagi masyarakat.

Utang adalah harta yang diberikan oleh seseorang yang memberi utang kepada orang yang berhutang, agar oranng yang berhutang mengembalikan barang yang serupa dengannya kepada orang yang memberikan utang. Secara bahasa, qardhmengandung arti pemotongan. Dan, harta yang diambil oleh orang yang berhutang disebut qardh karena orang yang memberi utang memotongnya dari hartanya.

Utang piutang yang dalam Islam disebut qardh merupakan salah satu bentuk ibadah untuk mendekatkan diri kepada Allah SWT. Sebab, dengan memberikan uang (atau barang yang lain) berari menyayangi manusia, mengasihi mereka, memudahkanurusan mereka, dan menghilangkan kesusahannya. Islam menganjurkan dan menyarankan bagi orang yang (berkecukupan) untuk memberikan pinjaman. Islam juga membolehkan (orang yang kesusahan) menerima hutangan dari orang yangmenghutanginya dan ia termasuk orang yang meminta-minta yang dimakruhkan. Sebab, orang yang meminjam atau berhutang mengambil harta atau barang dan dimanfaatkan untuk memenuhi kebutuhannya. Setelah itu mengembalikan harta atau barang yang dipinjamkannya (Sabiq, 2012: 234).

Hutang piutang memiliki rukun dan syarat di antaranya: pertama, Shighat yang dimaksud adalah ijab dan Kabul. Tidak ada perbedaan di antara fukaha bahwa ijab Kabul itu sah dengan lafaz utang dengan semua lafaz yang menunjukkan maknanya, seperti kata, "Aku memberimu hutang", atau "Aku mengutangimu". Demikian pula Kabul sah dengan semua lafaz yang menunjukkan kerelaan, seperti "Aku berutang" atau "Aku menerima", atau "Aku rida" dan sebagainya. Kedua, Aqidain, yaitu dua pihak yang melakukan transaksi atau pemberi dan pengutang. Adapun syarat-syarat bagi pengutang adalah merdeka, baliq, berakal sehat, dan pandai, Ketiga, harta yang diutangkan, rukun dari harta yang diutangkan adalah sebagai berikut: 1) harta berupaharta yang ada padanya, maksudnya harta yang satu sama lain dalam jenis yang sama tidak banyak berbeda yang mengakibatkan perbedaan nilai, seperti uang, barang- barang yang dapat ditakar, ditimbang, ditanam, dan dihitung, 2) harta yang diutangkan diisyaratkan berupa benda, tidak sah mengutangkan manfaat (jasa), 3) harta yang diutangkan diketahui, yaitu diketahui kadarnya dan diketahui sifatnya. (Mardani, 2016: 333)

Mayoritas masyarakat di Jorong Sungai Jambu penduduknya adalah sebagai petani. Dikarenakan daerah yang keadaan tanahnya sangat cocok untuk kegiatan pertanian. Sebagian masyarakat memilih untuk berkebun ubi. Hal ini dikarenakan pengelolaannya yang tidak terlalu sulit dan waku panen juga tidak perlu menunggu terlalu lama.

Keadaan cuaca sangat berpengaruh terhadap pengelolaan pertanian. Kedatangan musim panas dapat memperlambat proses pengembangan dan mempengaruhi hasil dari perkebunan 
ini. Hal ini menyebabkan petani mengalami hambatan panen dalam waktu yang cepat. Sementara kebutuhan setiap harinya tetap harus dipenuhi. Hal ini membuat para petani harus meminjam uang untuk pemenuhan kebutuhannya. Para petani biasannya memilih untuk meminjam kepada toke ubi karena proses transaksinya yang lebih cepat dibandingkan dengan peminjaman kepada lembaga keuangan bank ataupun non bank.

Ketika peminjaman, petani dan toke membuat perjanjian secara lisan bahwa ketika petani memanen ubi, ubi tersebut harus dijual kepada toke tempat peminjaman uang. Toke akan membeli ubi dengan harga yang ditetapkan sendiri yang harganya lebih rendah dari harga pasar. Pembayaran hutang dilaksanakan setelah petani menjual ubinya kepada toke, kemudian toke tersebut langsung memotong hasil penjualan sebanyak hutang petani, jika ada bersisa akan diberikan kepada petani, jika kurang petani akan melunasi keseluruhan hutang.

Berdasarkan hasil wawancara dengan ibu Mailis seorang petani ubi mengatakan "Saya meminjam uang sebesar Rp. 700.000,- kepada toke ubi untuk modal menanam ubi. Toke tersebut meminjamkan uang kepada saya dengan syarat setelah ubi itu dipanen Saya harus menjual ubi kepada toke tersebut dan pembayaran hutang tersebut dilakukan setelah penjualan ubi. (wawancara dengan Ibu Mailis petani ubi: 13 Agustus 2019). Dari hasil wawancara di atas dapat dilihat bahwa peminjaman uang dengan syarat penjualan ubi ini muncul beberapa persoalan, yaitu utang bersyarat dan toke menarik keuntungan dari peminjaman melalui diturunkannya harga.

\section{METODE PENELITIAN}

Jenis penelitian yang digunakan dalam penelitian ini yaitu penelitian lapangan (field research). Penelitian ini melalui pendekatan penelitian kualitatif, yaitu prosedur penelitian dengan hasil data deskriptif. Dalam penelitian ini peneliti akan meneliti pelaksanaan utang piutang dan proses pembayaran hutang petani ubi kepada toke ubi di Jorong Sungai Jambu. Penelitian yang penulis lakukan bertempat di Jorong Sungai Jambu Nagari Sungai Jambu Kecamatan Pariangan Kabupaten Tanah Datar. Dalam penelitian kualitatif instrumennya adalah peneliti sendiri. Insturmen pendukung yang penulis gunakan dalam penelitian ini adalah pedoman wawancara berupa daftar pertanyaan, guna mendapatkan data dari pihak petani ubi dan toke ubi di Jorong Sungai Jambu Nagari Sungai Jambu.

\section{HASIL DAN DISKUSI}

\section{A. Pelaksanaan Akad Transaksi Utang Petani Dengan Toke Ubi Di Jorong Sungai Jambu Nagari Sungai Jambu}

Pada Jorong Sungai Jambu terjadi transaksi utang piutang. Akad utang piutang yang dilakukan antara toke ubi dengan petani ubi di Jorong Sungai Jambu adalah utang piutang bersyarat. Akadnya yaitu seperti: buk Ermawati mengatakan kepada Al (toke ubi) "saya mau meminjam uang untuk modal menanam ubi, apakah bisa?", Al menjawab: "bisa kak, kakak perlunya berapa?", buk Ermawati menjawab: "saya perlunya sebanyak Rp. 800.000", Al 
mengatakan: "baik kak, tetapi kalau ubinya sudah bisa dipanen nanti ubinya jual kepada saya" buk Ermawati menjawab::" baik lah $\mathrm{Al}^{\prime}, \mathrm{Al}$ : "ambilkan dulu uangnya kak", buk Ermawati: "iya Al", Al: "ini uangnya kak, pembayaran hutangnya setelah panen ubinya ya kak, saya langsung memotong hasil penjualanubi kakak dengan hutang kakak", buk Ermawati: "baik $\mathrm{Al}$, terima kasih $\mathrm{Al}^{\prime}, \mathrm{Al}:$ " sama-sama kak". (hasil wawancara dengan Buk Ermawati sebagai petani ubi pada tanggal 22 Desember 2019).

Adapun hasil wawancara dengan toke ubi bahwa petani mendatangi toke dengan maksud untuk berhutang kepada toke. Toke menyetujui permintaan hutang uang kepadanya. Namun, toke mensyaratkan kepada petani ubi ketika panen ubi, ubi dijual kepadanya dan pembayaran hutang tersebut dibayarkan dengan cara pemotongan langsung dari hasil penjualan ubi tersebut. (hasil wawancara dengan Al sebagai ubi pada tanggal 23 Desember 2019). Selain pernyataan dari $\mathrm{Da} \mathrm{Al}$, penulis juga melakukan wawancara dengan Da Toni selaku toke ubi yang menyatakan bahwa hutang piutang yang dilakukan di Jorong Sungai Jambu Nagari Sungai Jambu ini pada prakteknya, sama dengan hutang piutang yang sebagaimana mestinya, tapi dengan syarat setelah petani ubi diberikan pinjaman uang oleh toke ubi disyaratkan hasil panen ubi petani harus dijual kepada toke ubi selaku pemberi pinjaman kepada petani serta pembayaran hutang tersebut dilakukan dengan cara memotong langsung hasil panen ubi petani. Hal ini dilakukan agar dalam pelunasan hutangnya petani tidak bertele-tele karena uang pinjaman tersebut bisa juga digunakan oleh toke untuk modal dalam mengembangkan usahanya.

Adapun mekanisme yang dilakukan dalam praktek hutang bersyarat di Jorong Sungai Jambu Nagari Sungai Jambu, yaitu:

1. Datang langsung kepada toke selaku pemberi hutang

2. Melakukan perjanjian terkait dengan besar pinjaman dan waktu jatuh tempo.

3. Harus memiliki jaminan berupa hasil panen ubi

4. Mengembalikan pinjaman sesuai dengan kesepakatan (wawancara dengan Da Toni selaku toke ubi pada tanggal 20 April 2020)

Mekanisme hutang piutang tersebut di dalam proses yang dilakukan lebih cepat dan mudah, perjanjian dilakukan hanya secara lisan dengan sistem kepercayaan, sehingga petani ubi selaku peminjam tidak memerlukan dokumen terkait identitas seperti halnya meminjam uang di lembaga keuangan.

Saat memberikan hutang piutang ini petani sebagai peminjam dan toke sebagai pemberi pinjaman sama-sama mendapatkan keuntungan, keuntungan bagi petani yaitu dengan adanya hutang yang diberikan oleh toke ubi, petani dapat menggunakan hutang tersebut sebagai modal mengolah sawahnya untuk ditanami ubi, seperti untuk membeli pupuk ubi, untuk upah membajak sawah, untuk upah orang menanam ubi dan menyiangi ubi. Selain itu juga untuk memenuhi kebutuhannya sehari-hari dan juga untuk keperluan anak mereka sekolah atau kuliah. Keuntungan bagi toke ubi sebagai pemberi hutang yaitu agar dapat mengembangkan usahanya, dengan memberikan syarat kepada petani yangberhutang agar menjual ubi kepadanya, toke lebih mudah mendapatkan ubi apabila ada banyak permintaan ubi (wawancara dengan Da Nok sebagai toke ubi pada tanggal 24 Desember 2019) 
Dari penelitian yang penulis lakukan di Jorong Sungai Jambu Nagari Sungai Jambu dengan petani dan toke yang melakukan utang piutang bersyarat, yang menjadi alasan bagi petani untuk meminjam uang kepada toke dengan bersyarat adalah untuk mengolah sawahnya untuk ditanami ubi, untuk kebutuhan sehari- hari dan untuk biaya pendidikan anak petani tersebut. dan alasan toke melakukan utang piutang bersyarat adalah agar dalam pembayaran hutang petani tidak bertele-tele dan untuk mengembangkan usahanya.

\section{B. Mekanisme Pembayaran Utang Uang Yang Dilakukan Oleh Petani Ubi Terhadap Toke Ubi}

Utang piutang yaitu memberikan sesuatu kepada seseorang dengan perjanjian dia akan membayar yang sama dengan itu (Arianti, 2014: 22). Orang yang berutang wajib mengembalikan pinjaman bila telah jatuh tempo pelunasan. Dan bagi yang mampu melunasi, haram hukumnya menunda-nunda pembayaran (Rijal, 2013: 99).

Mekanisme pembayaran hutang antara petani ubi dengan toke di Jorong Sungai Jambu Nagari Sungai yaitu dari hasil jual beli ubi, yang mana toke yang memberikan hutang kepada petani yang membeli ubi petani tersebut. Pada akad jual beli ubi ini toke mensyaratkan tersebut dengan penjualan hasil ubinya secara keseluruhan kepada toke, meskipun hasil tanaman ubinya jauh lebih banyakharganya dari hutang petani (wawancara dengan Def sebagai petani ubi pada tanggal 23 Desember 2019).

Dari hasil penjualan ubi tersebut toke langsung memotong uang penjualan ubi untuk pembayaran hutang petani. Sesuai dengan penjelasan dari petani ubi: Al: "ubi di kayu aro lah patuk di ungkoa mah kak", Mailis: "iyo Al", Al: "bia lah bisuek wak ambiak lai kak, Mailis: "jadih al ndk baa da al", Al: "bisuek pitih ubi kak ko langsuang jo wak potong samo utang kak potang, kan utang kak 1.000.000 potang mah, jadi lobie jo wak agin ka kak bisuek", Mailis: "jadih Al ndak baa da Al, bisuek anton jo pitih ka rumah $\mathrm{Al}$, Al::"jadih kak". (Al: ubi yang di kayu aro sudah bisa di panen kak, Mailis: iya Al, Al: besok saya yang memanen ubinya, Mailis: ok Al, Al: uang hasil panen ubinya langsung saya potong dengan hutang, kan hutang nya 1.000.000, jadi uang lebihnya saya berikan kepada kakak, Mailis: ok Al, besok uangnya diantarkan saja ke rumah, Al: iya kak) (hasil wawancara dengan mailis sebagai petani ubi pada tanggal 23 Desember 2019).

Pembayaran hutang yang dilakukan antara petani ubi dengan toke ubi di Jorong Sungai Jambu adalah dengan cara pemotongan langsung dari hasil penjualan ubi petani dan dari penjualan ubi petani tersebut terdapat perbedaan harga antara petani ubi yang meminjam uang kepada toke dengan petani yang tidak meminjam uang kepada toke. Hal ini sesuai dengan hasil wawancara Ibuk Ermawati selaku petani ubi, yang mengatakan bahwa beliau membayar hutang yang diberikan toke ubi dengan cara toke ubi memotong langsung dari hasil penjualan ubi serta toke juga mengambil upah mencuci ubi dan mengangkut ubi dari sawah ke tepi jalan dari hasil ubi tersebut. Beliau juga mengatakan bahwa ubinya yang dibeli toke tersebut lebih rendah dari harga pasaran, sedangkan toke membeli ubi petani yang tidak meminjam uang kepada sesuai dengan harga pasaran. Dan tidak ada kesepakatan pada saat akad bahwa toke akan memotong harga jual beli ubi, toke hanya mengatakan memotong harga jual beli ubi tersebutketika hasil penjualan ubi diberikan kepada beliau (wawancara dengan buk Ermawati sebagai petani ubi pada tanggal 22 Desember 2019). Berdasarkan hasil 
wawancara di atas terlihat bahwa adanya perbedaan harga ubi antara petani ubi yang berhutang kepada toke dengan petani yang tidak berhutang kepada toke. Dan juga toke memotong harga dari penjualan ubi petani tanpa adanya kesepakatan awal dengan petani.

Alasan toke memotong harga seperti yang disampaikan petani ubi untuk mendapatkan keuntungan sesuai dengan hasil wawancara dengan toke ubi yang mengatakan bahwa benar, saya memotong harga kepada orang yang meminjam uang kepada saya, sistemnya hampir sama dengan bank, kalau di bank kita meminjam uang akan memakai bunga, jadi dari situ saya mengambil keuntungan, sambil menolong, petanimterbantu dan saya juga dapat mengambil keuntungan (wawancara dengan Da Al sebagai toke ubi pada tanggal 23 Desember 2019).

Dengan adanya pemotongan harga ubi seperti yang dijelaskan di atas petani ubi merasa dirugikan, seperti yang disampaikan petani ubi yang menjelaskan bahwa beliau merasa dirugikan dengan adanya pemotongan harga ubi tersebut, beliau menjual ubi kepada toke yaitu 15 karung ubi besar, 3 karung ubi menengah, dan 2 karung ubi yang kecil, kalau diambil kerugian dari ubi yang besar saya rugi seratus lima puluh ribu belum lagi dari ubi yang kecil danmenengah, toke mengambil banyak keuntungan dari penjualan ubi tersebut (wawancara dengan Ibu Ermawati sebagai petani ubi pada tanggal 22 Desember2019).

Penulis melihat adanya kerugian yang ditimbulkan hutang bersyarat ini yaitupetani harus menjual ubi secara keseluruhan kepada toke dengan harga yang jauh dari harga pasaran. Misalkan: petani meminjam uang Rp. 800.000 kemudian hasil ubi ada 20 karung, harga per karung Rp. 150.000, sedangkan harga yang diberikan kepada petani yang berhutang kepada toke adalah Rp. 140.000 per karung. Jika dengan harga normal, maka petani akan mendapatkan uang sebesar Rp. 3.000.000, sedangkan petani yang berhutang hanya mendapatkan uang sebesar Rp. 2.800.000. Jadi, terdapat selisih harga Rp. 200.000, jika petani berhutang sebesar Rp. 800.000.

\section{Tinjauan Fikih Muamalah Terhadap Pelaksanaan Hutang Dengan Bersyarat Dan Mekanisme Pembayaran Hutang Menurut Fikih Muamalah}

Akad utang piutang merupakan kebajikan yang telah diisyaratkan dalam Islam. Hukumnya Mubah atau Boleh (Syarifuddin, 2010: 222). Tujuan diperbolehkannya utang piutang itu adalah untuk memberikan kemudahan bagi umat manusia, manusia itu ada yang berkecukupan dan ada yang berkekurangan. Orang yang berkurangan memanfaatkan utang dari pihak yang berkecukupan dimana ia bisa menolong sesama umat.

Hutang merupakan akad tabarru". Akad tabarru" merupakan akad yang dimaksudkan untuk menolong sesana dan murni semata-mata mengharap ridha dari dan pahala dari Allah SWT, sama sekali tidak ada unsur mencari return, ataupun suatu motif. Dalam akad tabarru", pihak yang berbuat kebaikan tidak berhak mengharapkan mensyaratkan imbalan apapun kepada pihak lain. Imbalan dari akad tabarru" dari Allah SWT, bukan dari manusia. Namun, demikian pihakyang berbuat kebaikan tersebut boleh meminta kepada counter part-nya untuk sekedar menutupi biaya yang dikeluarkan untuk melakukan akad tabarru "itu.

Pada hakekatnya, akad tabarru" adalah akad melakukan kebaikan yang mengharapkan balasan dari Allah SWT semata. Itu sebabnya akad ini tidak bertujuan untuk mencari 
keuntungan komersil. Konsekuensi logisnya, bila akad tabarru" dengan mengambil keuntungan, maka dia bukan lagi akad tabarru" ia akan menjadi akad tijarah. Bila seseorang mengambil ingin tetap menjadi akad tabarru", maka ia tidak boleh mengambil manfaat atau keuntungan dari akad tersebut (Ichsan, 2016: 404-405).

Sesuai dengan uraian di atas akad hutang piutang bersyarat yang tejadiantara pertain ubi dengan toke ubi di Jorong Sungai Jambu Kecamatan ParianganKabupaten Tanah Datar bertentangan dengan prinsip akad tabarru", karena dalam pemberian hutang toke mengambil keuntungan dari akad hutang piutang tersebut, dengan memberikan syarat kepada petani ubi untuk menjual hasil panen ubinya kepada toke.

Selain itu akad utang bersyarat yang di lakukan oleh petani ubi dengan toke ubi di Jorong Sungai Jambu Nagari Sungai Jambu hukumnya tidak sah atau rusak. Karena dalam akad utang piutang bersyarat yang dilakukan di Jorong Sungai Jambu terdapat syarat yang diajukan oleh toke kepada petani ubi yang meminjam uang untuk menjual ubinya kepada toke dengan tujuan untuk kepentingan dirinya. Hal ini juga dijelaskan oleh 4 imam mazhab, yaitu:

1. Hanafiah memakruhkan seseorang yang berutang sesuatu kepada orang lain untuk memperoleh manfaat tertentu bila itu disyaratkan dalam akad. Misalnya seseorang mengutangkan gandum yang kotor kemudianmensyaratkan agar orang tersebut untuk membayarnya dengan gandum yangbersih.

2. Malikiyah berpendapat bahwa haram dalam utang piutang menentukan sarat untuk mendapat manfaat, misalnya mensyaratkan membayar utang dengan hewan yang sehat padahal hewan yang dihutangkan lemah.

3. Hanabilah menyebutkan bahwa dalam hutang piutang tidak boleh mensyaratkan sesuatu untuk mendapat manfaat tambahan bagi yang mengutangkan atau dengan syarat memberikan hadiah dan lain sebagainya.

4. Sedangkan syafi'I memberikan beberapa ketentuan dalam hal hutang piutangbersyarat ini, yaitu:

a. Apabila sarat yang diberikan itu bertujuan untuk mengambil manfaat untuk kepentingan orang yang berpiutang, maka dalam hal ini akadutangnya rusak dan hukum hutangnya tidak sah atau haram

b. Apabila sarat yang diberikan itu bertujuan untuk mengambil manfaat untuk kepentingan orang yang berhutang, maka dalam hal ini syaratnya rusak, sedang akadnya sah.

c. Apabila syarat yang diberikan hanya digunakan untuk kepercayaan, seperti disyaratkan bagi pihak yang berutang untuk memberikan sertifikat tanah sebagai jaminan utangnya kepada orang yang berpiutang, maka yang demikian itu dapat dibenarkan menurut Hukum Islam.

Dari dari uraian di atas dapat dilihat bahwa pelaksanaan jual beli ubi yang antara petani ubi dengan toke ubi yang menjadi syarat pembayaran hutang yang dilakukan di Jorong Sungai Jambu tidak memenuhi syarat dari jual beli, yang mana jual beli ubi ini tidak memenuhi syarat dari subjek jual beli. Syarat dari subjek jual beli, yaitu:

a. Berakal 
Dengan demikian, jual beli yang dilakukan anak kecil yang belum berakal, hukumnya tidak sah. Anak kecil yang sudah mumayyiz (menjelang baligh), apabila akad yang dilakukannya membawa keuntungan baginya,seperti menerima hibah, wasiat, dan sedekah, maka akadnya sah menurut Mazhab Hanafi. Yang dimaksud dengan berakal adalah dapat membedakan atau memilih mana yang terbaik bagi dirinya. Apabila salah satu pihak tidak berakal maka jual beli yang diadakan tidak sah. (Lubis, 2000: 30).

Sebaliknya apabila akad itu membawa kerugian bagi dirinya, seperti meminjamkan harta kepada orang lain, mewakafkan atau menghibahkannya tidak dibenarkan menurut hukum.

Transaksi yang dilakukan anak kecil yang mumayyiz yang mengandung manfaat dan mudarat sekaligus, seperti jual-beli, sewa-menyewa dan perserikatan dagang, dipandang sah menurut hukum dengan ketentuan bila walinya mengizinkan setelah dipertimbangkan dengan sematang-matangnya ( Hasan, 2004: 118-119).

b. Dengan Kehendak Sendiri (Bukan Terpaksa)

Dalam melakukan perbuatan jual beli, salah satu pihak tidak melakukan tekanan atau paksaan atas pihak lain. Akibatnya, pihak lain tersebut melakukan perbuatan jual beli bukan disebabkan kemauan sendiri, tetapi karena ada unsur paksaan.

Adapun yang menjadi dasar bahwa suatu jual beli harus dilakukan atas dasar kehendak sendiri, dapat dilihat dalam ketentuan Q.S An-Nissa ayat 29 yang artinya: "hai orang-orang yang beriman, janganlah kamu saling memakan harta sesamamu dengan jalan yang bathil, kecuali dengan jalan perniagaan yang berlaku dengan suka sama suka di antara kamu" (Lubis, 2000: 30)

c. Keduanya tidak mubazir

Pihak yang mengikatkan diri dalam perjanjian jual beli bukanlah manusia yang boros (mubazir), sebab orang yang boros di dalam hukum dikategorikan sebagai orang yang tidak cakap hukum. Maksudnya, dia tidak dapat melakukan sendiri sesuatu perbuatan hukum, walaupun kepentingan hukum itu menyangkut kepentingan sendiri. (Lubis, 2000: 31)

d. Baligh

Orang yang sudah cukup umur dan dapat membedakan mana yang baik dan mana yang buruk, maka jual beli yang dilakukan oleh anak kecil adalah tidak sah (Hasan, 2004: 119 ). Syarat subjek jual beli yang tidak terpenuhi pada penjualan ubi di Jorong Sungai Jambu Nagari Sungai Jambu adalah dengan kehendak sendiri atau bukan terpaksa. Sedangkan yang terjadi di Jorong Sungai Nagari Sungaiadanya keterpaksaan petani untuk menjual hasil panen ubinya kepada toke, karena itu merupakan syarat dari hutang dan toke membeli ubi petani lebih rendah dari harga pasar.

Dari uraian di atas dapat dilihat bahwa jual beli ubi di Jorong Sungai Jambu Nagari Sungai Jambu bukan termasuk jual beli yang sah menurut hukum. Karenajual beli yang sah adalah jual beli yang sesuai dengan perintah syariat dan memenuhi rukun serta syarat jual beli. Dengan terpenuhinya rukun dan syarat ini, kepemilikan atas barang yang dijual dan penukarnya serta pemanfaatan keduanyamenjadi halal. Jika jual beli bertentangan dengan perintah syariat, maka jual beli dinyatakan tidak sah dan batal. Sedangkan jual beli ubi yang terjadi di Jorong Sungai Jambu Nagari Sungai Jambu telah memenuhi rukun dari jual beli, tetapi tidak memenuhi syarat dari jual beli, yaitu syarat dari subjek jual beli. Sehingga, jual beli 
ubi yang terjadi di Jorong Sungai Jambu Nagari Sungai Jambu tidak sah atau batal menurut hukum Islam.

Pelaksanaan jual beli ubi antara petani ubi dengan toke ubi yang menjadi syarat pembayaran hutang yang dilakukan di Jorong Sungai Jambu dikategorikanakad fasid karena tidak memenuhi syarat-syarat keabsahan akad, meskipun rukundan syarat terbentuknya akad telah terpenuhi akad tidak sah. Akad ini sikategorikan sebagai akad fasid. Rukun pertama yaitu para pihak, harus memenuhi dua syarat terbentuk akad yaitu tamyiz dan terbilang. Dalam akad jual beli ubi ini dilakukan oleh orang yang tamyiz dan berbilang. Rukun kedua pernyataan dan kehendak harus memenuhi dua syarat juga, yaitu (1) ijab dan qabul, dengan kata lin tercapainya kata sepakat, (2) kesatuan majelis akad. Dalam akad jual beli ubi syarat ini terpenuhi dimana petani minta pinjaman uang kepada toke dan toke mengabulkan permintaan dari petani ubi tersebut danmemberikan syarat untuk menjual ubi kepada toke. Rukun ketiga objek akad, harus terpenuhi syarat yaitu, yaitu (1) objek yang dapat diserahkan, (2) tertentu dan dapat ditentukan, (3) dapat di transaksikan. Dalam jual beli ubi objek tersebut adalah ubi yang dapat ditransaksikan.

Menurut mazhab Hanafi, akad fasid adalah "akad yang menurut syarak sah pokoknya, akan tetapi tidak sah sifatnya", maksudnya adalah akad yang telah memenuhi rukun dan syarat terbentuknya, tetapi belum memenuhi syarat keabsahannya. Rukum pertama, yaitu pihak dengan dua syarat terbentuknya yaitu tamyiz dan terbilang, tidak memerlukan sifat penyempurna dalam akad jual beli ubi rukun ini terpenuhi. Rukun kedua, yaitu pernyataan kehendak dengan kedua syaratnya, juga tidak memerlukan sifat penyempurna, yaitu persetujuan ijab qabul itu harus dicapai secara bebas dan tanpa paksaan, bila mana terjadi paksaan, maka akadnya fasid. Dalam akad jual beli ubi ijab qabul dilakukan dengan terpaksa karena petani yang meminjam uang kepada toke, harus menjual ke toke yang meminjamkan uang. Rukun ketiga, yaitu objek akad, dengan ketiga syaratnya memerlukan sifat-sifat sebagai unsur penyempurna, yaitu bahwa penyerahan itu tidak menimbulkan kerugian (dharar) atau kerugian dimana ubi yang di jual kepada toke ubi yang meminjamkan uang tersebut dikurangkan harganya Rp. 10.000- Rp20.000/ karung, maka dari itu petani merasa dirugikan atas pengurangan harga tersebut.

Dari penelitian yang penulis lakukan di Jorong Sungai Jambu tentang jual beli antara petani ubi dengan toke ubi terdapat pemotongan harga jual beli ubi tersebut. Yang mana seharusnya harga ubi perkarungnya adalah Rp. 150.000, tetapi toke hanya membeli dengan harga Rp. 130.000 perkarung. Toke ubimemotong keseluruhan harga dari hasil panen ubi dari petani. Dari pemotongan harga tersebut toke mengambil keutungan di dalamnya. Hal ini sesuai dengan hasil wawancara penulis: Alasan toke memotong harga seperti yang disampaikan petani ubi untuk mendapatkan keuntungan sesuai dengan hasil wawancara dengan toke ubi yang mengatakan bahwa benar, saya memotong harga kepada orang yang meminjam uang kepada saya, sistemnya hampir sama dengan bank, kalau di bank kita meminjam uang akan memakai bunga, jadi dari situ saya mengambil keuntungan, sambil menolong, petani petani terbantu dan saya juga dapat mengambil keuntungan (wawancara dengan $\mathrm{Da} \mathrm{Al}$ sebagai toke ubi pada tanggal 23 Desember 2019). 
Dari uraian penulis di atas, dapat disimpulkan bahwa akad hutang piutang yang terjadi di Jorong Sungai Jambu Nagari Sungai Jambu merupakan akad yangbertentangan dengan akad tabarru", karena dalam memberikan hutangnya toke memberikan syarat agar petani ubi yang berhutang kepadanya harus menjual hasil ubi kepadanya. Kemudian di dalam jual beli ubi terdapat unsur keterpaksaan dan toke mengambil keuntungan yang bukan merupakan haknya.

\section{KESIMPULAN}

Dari hasil penelitian yang penulis lakukan mengenai Tinjauan Fiikih Muamalah Terhadap Pembayaran Hutang Uang Melalui Penjualan Ubi Studi Kasus di Jorong Sungai Jambu Nagari Sungai Jambu Kecamatan Pariangan Kabupaten Tanah Datar, dapat diambil kesimpulan bahwa:

1. Dari penelitian yang penulis lakukan, akad hutang piutang yang dilakukan antara petani ubi dengan toke ubi di Jorong Sungai Jambu Nagari Sungai Jambu termasuk kepada hutang bersyarat. Karena pada saat peminjaman kepada petani toke mensyaratkan agar petani menjual ubinya kepada petani.

2. Proses pembayaran hutang petani kepada toke yaitu dengan cara petanimenjual ubinya kepada toke. Dari penjualan tersebut adanya kerugian dari petani ubi karena toke ubi membeli ubi petani jauh di bawah harga pasaran dan menurunkan harga keseluruhan dari hasil panen ubi petani.

3. Berdasarkan tinjuan fikih muamalah akad hutang piutang yang terjadi di Jorong Sungai Jambu Nagari Sungai Jambu merupakan akad yang bertentangan dengan akad tabarru", karena dalam memberikan hutangnya toke memberikan syarat agar petani ubi yang berhutang kepadanya harus menjual hasil ubi kepadanya. Kemudian di dalam jual beli ubi terdapat unsur keterpaksaan dan toke mengambil keuntungan yang bukan merupakan haknya.

\section{DAFTAR PUSTAKA}

Al-Albani, M. N. (2011). Fikih Sunnah. Jakarta: Cakrawala Publishing.

Arianti, F. 2014. Fikih Muamalah II. Batusangkar: Stain Batusangkar Press

Arifin, Z. (2013). Tinjauan Hukum Islam Terhadap Praktik Pinjaman Di Koperasi PT Djarum Kudus. Syariah. Universitas Islam Negri Sunan Kalijaga Yogyakarta. Yogyakarta

Basyir, A. A. (2000). Asas-asas Hukum Muamalat (Hukum Perdata Islam). Yogyakarta: UII Press Binjai, A. H. H. (2006). Tafsir Al-Ahkam. Jakarta: Kencana Prenada Media Group

Ghofur, A. (2016). Konsep Riba Dalam Al-Qureean. Volume VII. journal.walisongo.ac.id. 3 Oktober 2019

Haroen. (2000). Fiqh Muamalah. Jakarta: Gaya Media Pratama

Hidayanto, M. F. (2008). Praktek Riba dan Kesenjangan Sosial. Vol. II. journal.uii.ac.id. 3 Oktober 2019 
Hulaify, A. (2019). Asas-asas Kontrak (Akad) Dalam Hukum Syarieah. ojs.uniska.ac.id/attadbir. 2 oktober 2019

Lubis, S. K. (2000). Hukum Ekonomi Islam. Jakarta: Sinar Grafika Nasrun.

Mahmud, T. (2013). Memakan Harta Secara Bathil (Perspektif Surat An-Nisa: 29 dan AtTaubah: 34). Vol 17.

Maulana, H. (2011). Multi Akad Dalam Transaksi Syariah Kontemporer Pada Lembaga Keuangan Syariah di Indonesia. Vol III. journal.uinjkt.ac.id. 2 Oktober 2019

Hasan, M. A. (2004). Berbagai Transaksi Dalam Islam. Jakarta: Raja Grafindo

Muslich, W. A. (2010). Fiqh Muamalah. Jakarta: Amzah

Putri, S. E. (2018). Pemetaan Jaringan Sosial dalam Organisasi: Studi Pada Distributor Tupperware Unit Simabur Indah di Batusangkar Sumatera Barat. Jurnal Antropologi: Isuisu Sosial Budaya Vol. 20 No. 2 Tahun 2018 (hal 141)

Putri, S. E. (2020). Upacara Kematian Pada Masyarakat Nagari Taluak Kecamatan Lintau Buo Kabupaten Tanah Datar Dalam Perspektif Hukum Islam. Jurnal Ilmiah Syariah. Vol. 19. No 1.

Rijal, A. (2013). Utang Halal Utang Haram. Jakarta: Pt Gramedia Pustaka Utama

Rohman, A. (2016). Menyoal Filosofi An Taradin Pada Pada Jual. Volume 3.

Sabiq, S. (2012). Fikih Sunnah 5. Jakarta: Cakrawala Publishing

Sahrani. S. dkk. (2011). Fikih Muamalah. Bogor: Ghalia Indonesia

Siswadi. (2013). Jual Beli Dalam Perspektif Islam. Vol III. ejornal.kopertais4.or.id.

Sudirma, D. (2002). Menjadi Peneliti Kualitatif. Jakarta: Pustaka Setia

Suhendi, H. (2002). Figh Muamalah. Jakarta: PT. Raja Grafindo Persada

Susiawati, W. (2017). Jual Beli dan Dalam Konteks Kekinian. Vol. 8. http://journal.uhamka.ac.id/index.php/jei. 3 Oktober 2019

Sugiyono. (2008). Memahami Penelitian Kualitatif. Bandung:CV. Alfabeta

Syafe'i, R. (2004). Fiqh Muamalah. Bandung: Pustaka Setia.

Syarifuddin, A. (2010). Garis-Garis Besar Fiqh. Jakarta: Kencana Prenada Media Group

Umamah, C. (2013). Pinjaman Bersyarat Dalam Tinjauan Hokum Islam (Studi Di Dusun Tegalsari.

Desa Kawungantenlor. Kec.Kaunganten.Kab. Cilacap. Fakultas Syariah. Universitas Islam

Negeri Sunan Kalijaga Yogyakarta. Yogyakarta

Wahab, M. A. (2018). Fiqh Pinjam Meminjam (,Ariyah). Jakarta: Rumah Fiqih Publishing

Wahab, F. (2017). Riba: Transaksi Kotor Dalam Ekonomi. ejournal.alqolam.ac.id.

Wahbah, A. (2011). Fiqih Islam 5. Jakarta: Gema Insani

Wahyuddin, I. (2016). Tinjauan Hukum Islam Terhadap Hybrid Kontrak Dalam Akad Syariah. journal.uii.academia.edu. 